\title{
Hydraulic Conductivity of Subsoils of Lajas Valley ${ }^{1}$
}

\author{
M. A. Lugo-López and R. Pérez-Escolar ${ }^{2}$
}

\section{INTRODUCTION}

Hydraulic conductivity of subsoils is considered to be one of the most important soil characteristics. It must be considered in the design of irrigation and drainage systems $(1)^{3}$ and of soil and water conservation structures (4). Furthermore, it is used as one of the key factors in soil classification surveys. Essentially, it is a measure of water movement through a column of soil.

Hydraulic conductivity is one of the most difficult soil factors to evaluate quantitatively (1). It is extremely difficult for soil surveyors in fieldwork to estimate upon inspection the hydraulic conductivity of subsoils, one of the required properties for characterizing soils. This paper reports hydraulic-conductivity data for the major soil series of Lajas Valley, an area in southwestern Puerto Rico where an irrigation-drainage development project is under construction. The purpose is to present data that might serve as a guide for soil surveyors in estimating hydraulic values for the soils included in the study. For this purpose replicated measurements were made in an attempt to determine the range of values that might characterize each of the major soils of the Valley.

\section{THE SOILS STUDIED}

In this study 23 profiles from Lajas Valley were included comprising the major soils of the area. Soils of the Aguirre, Guánica, Santa Isabel, San Antón, Fraternidad, Fe, and Jácana series were studied (3). These soils are generally very deep with a strikingly high, almost uniform clay content of the expanding-lattice type, predominantly small pores, very low aggregate stability below the surface layer, very slow hydraulic conductivity in the subsoil, but with a topsoil of 1 or 2 feet that conducts water rather well. They are relatively low in organic matter and nitrogen, and generally high in soluble salts and exchangeable sodium, both of which increase with depth.

1 Joint contribution from the Gurabo Substation and the Department of Soils of this Station.

2 Soil Scientist in Charge of the Gurabo Substation and Assistant Soil Scientist, respectively, Agricultural Experiment Station, University of Puerto Rico, Río Piedras and Gurabo, P.R. Appreciation is expressed to G. Acevedo, Research Assistant in soils who helped in some of the field and laboratory work.

${ }^{3}$ Italic numbers in partheses refer to Literature Cited, p. 277. 


\section{METHODS}

The sampling was done as a part of a more extensive study on the nature and properties of the major soils of Lajas Valley (3). Pits 4 feet wide, 4 feet long, and 6 feet deep were dug at 23 selected, scattered, and distant places mainly along the eastern and central sections of the lower Valley. The soils were described and sampled throughout each layer. Undisturbed soil cores were taken with a Uhland sampler, 3 inches in diameter by 3 inches in length. Four cores were taken from each layer.

Subsoil hydraulic-conductivity measurements were made on the undisturbed cores by recording the rate at which water moved through a column of saturated soil at a known head.

TABLE 1.-Subsoil hydraulic-conductivity values in major soils of Lajas Valley Irrigation Development Project

\begin{tabular}{l|c|c|c}
\hline Soil series & Samples & $\begin{array}{c}\text { Mean hydraulic } \\
\text { conductivity }\end{array}$ & $\begin{array}{c}\text { Range of hydraulic } \\
\text { conductivity values }\end{array}$ \\
\cline { 2 - 3 } & Number & In. per hr. & In. per hr. \\
Aguirre & 24 & 0.057 & $<0.005-0.29$ \\
Guánica & 16 & .046 & $<.005-.09$ \\
Fraternidad & 20 & .055 & $<.005-.11$ \\
Fe & 12 & .101 & $<.005-.23$ \\
San Antón & 8 & .220 & $.11-.33$ \\
Santa Isabel & 4 & .050 & .05 \\
Jácana & 8 & .032 & $<.005-.06$ \\
\hline
\end{tabular}

\section{RESULTS AND DISCUSSION}

Table 1 gives mean hydraulic conductivity and the range of values for subsoils of the major soil series of the Lajas Valley. As can be observed, hydraulic conductivity is slow in all the subsoils. In magnitude they could be ranked: San Antón $>\mathrm{Fe}>$ Aguirre $=$ Fraternidad $=$ Santa Isabel $>$ Guánica > Jácana.

The slow water movement in these subsoils can be explained on basis of the nature and size of the soil voids. Although all these subsoils have a high porosity, most of the pores are very small as revealed by water retention when low tensions develop $(3)$. Furthermore, subsoil aggregates are very unstable (2), and disperse quickly upon wetting, thus clogging soil voids.

Previous studies have shown that the topsoil, usually 1 or 2 feet in depth, can conduct water rather well as compared to the subsoils (3) (fig. 1). In some Guánica soils water moves in the upper 2 feet at rates over 1 inch per hour; in some Fe, Fraternidad, and Aguirre soils extremely fast rates of over 5 inches have been recorded, more so in the uppermost 6 -inch layer.

The slow hydraulic-conductivity values in the subsoils complicate the 
management of the irrigated soils of the Lajas Valley. Comprehensive drainage and cropping programs must take account of this fact. The Jácana soils occurring at higher elevations throughout the Valley have better

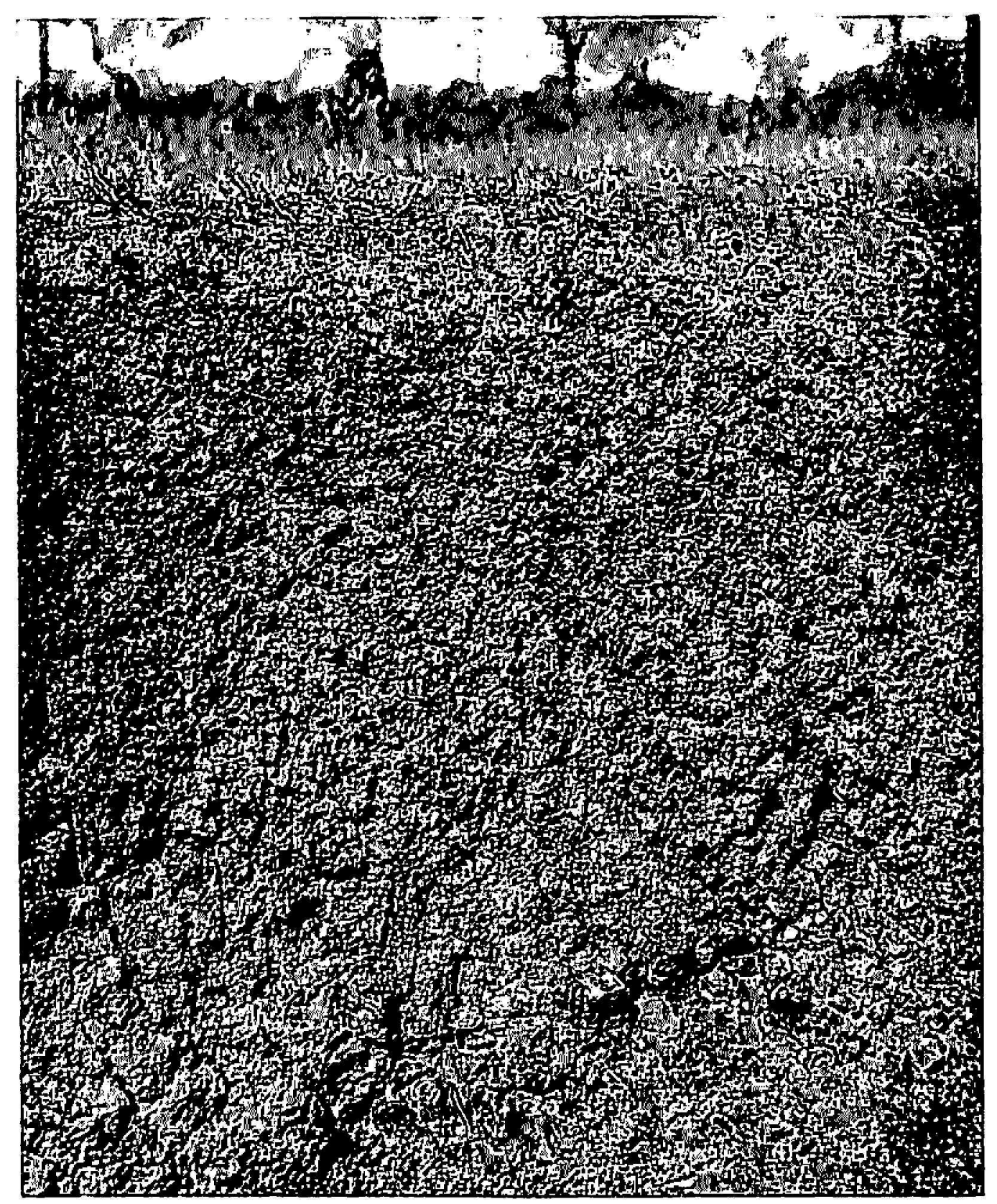

Fig. 1.-Most of the Lajas Valley soils have a topsoil with favorable structure that conducts water rather well. Subsoils are tighter, with weak unstable aggregates.

surface drainage than other soils. The Fraternidad and Fe soils (fig. 2), on the long, gently sloping alluvial fans rank next as to surface drainage, but in the Aguirre and Guánica soils of the lower Valley waterlogging would result if open channels were not available.

The exceedingly slow hydraulic-conductivity of subsoils together with 
the very low stability of aggregates in most soils of the Valley constitute a large potential danger. Light, frequent irrigations gaged to conform with these limitations can be the key to successful farming over the Valley.

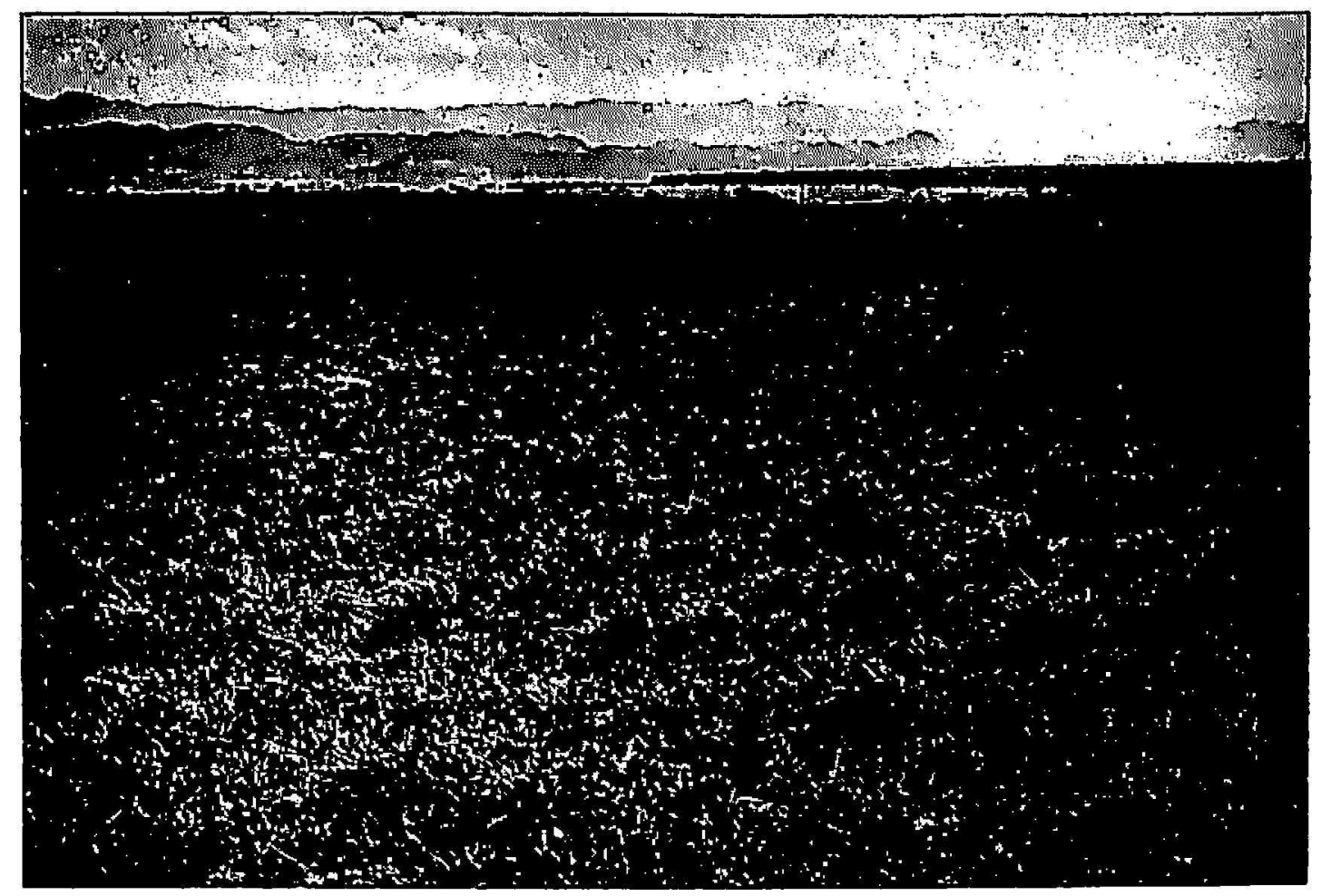

Fig. 2.-The Fraternidad and Fe soils on gently sloping lands have better surface drainage but subsoil hydraulic conductivity is slow.

\section{SUMMARY}

Data are presented here on the hydraulic conductivity of subsoils of major soils from the Lajas Valley Irrigation Drainage Project. The data reveal that subsoil hydraulic conductivity is very slow in all cases. In some cases favorable features are the gently sloping topography at the upper Valley and the fact that topsoils generally conduct water rather well. Careful soil-management and cropping programs should take account of these facts, recognizing the limitations involved.

\section{RESUMEN}

Se presentan aquí datos sobre la conductividad hidráulica en los subsuelos de los suelos de mayor importancia en el Valle de Lajas. Los datos revelan que el movimiento de agua en estos subsuelos es lento en todos los casos estudiados. La topografía, ligeramente inclinada en algunos casos, y el hecho de que el movimiento del agua en las capas superficiales de los suelos es bastante bueno, son factores favorables. Los programas sobre el manejo 
de estos suelos y sobre las cosechas, deben tomar ventaja de estos hechos, reconociendo, al mismo tiempo, las limitaciones inherentes.

\section{LITERATURE CITED}

1. Donnan, W. W., Field experiencies in measuring hydraulic conductivity for drainage design, Agr. Eng. 40(5) 270-3, 280, 1959.

2. Lugo-López, M. A., and Juárez, Jr. J., Evaluation of the effects of organic matter and other soil characteristics upon the aggregate stability of some tropical soils, J. Agr. Univ. P.R. 43(4) 268-72, 1959.

3. Lugo-López, M. A., Pérez-Escolar, R., Acevedo, G., and Juárez, Jr. J., Nature and Properties of Major Soils of the Lajas Valley, Univ. P.R. Agr. Exp. Sta. Bul. 149, 1959.

4. Uhland, R. E., and O'Neal, A. N., Soil Permeability Determinations for Use in Soil and Water Conservation, USDA, SCS Tech. Paper 101, 1951. 